\title{
Identification of Volatile Compound in Coconut Milk Samples Using GC-MS
}

\author{
S. Kokilavani ${ }^{1^{*}}$, G. Sashidevi², P. Venilla ${ }^{2}$ and R. Arun Kumar ${ }^{3}$ \\ ${ }^{1}$ Food Science and Nutrition, Madurai District, Tamil Nadu, India \\ ${ }^{2}$ Home Science College and Research Institute, Madurai District, Tamil Nadu, India \\ ${ }^{3}$ Horticulture, Krishi Vigyan Kendra, Agriculture College and Research Institute, Tamil Nadu \\ Agricultural University, Tamil Nadu, India \\ *Corresponding author
}

\section{A B S T R A C T}

\begin{tabular}{|l|}
\hline Ke y w o r d s \\
Coconut milk, \\
$\begin{array}{l}\text { Coconut milk } \\
\text { processing, GC-MS } \\
\text { analysis, Chemical } \\
\text { component. }\end{array}$ \\
\hline Article Info \\
\hline $\begin{array}{l}\text { Accepted: } \\
10 \text { September } 2017 \\
\text { Available Online: } \\
10 \text { November } 2017\end{array}$ \\
\hline
\end{tabular}

Keywords

Coconut milk,

processing, GC-MS

\section{Introduction}

Coconut milk, a white opaque liquid, is an emulsion of natural oil in water, extracted from shredded coconut endosperm (Cocos nucifera L.) either with or without the addition of water (Simuaug et al., 2004; Tangsuphoom and Coupland, 2005). Coconut milk, the processed and packed milk extracted from fresh matured coconuts is an instant product which can either be used directed or diluted with water to make various preparations such as curries, sweets, desserts, puddings (Anjaya et al., 1996). Coconut milk used as a food ingredient, and also it is an importance substance for health promotion and medicine. Coconut milk may be considered as a substitute for cow milk. It may be used by the people who cannot tolerate cow milk (Rehman et al., 2004). Phospholipids, cephalin and lecithin which have been found in coconut milk (Philippine coconut authority, 2014). Coconut milk is rich in antioxidants, which prevents free radical damage and delay the ageing process. A glass of coconut milk while taking other antioxidants rich foods, such as pecans, raisins and cranberries may boost the immunity while rebuilding the damaged cells in the body (Brown, 2014). It provides fat that is mostly in the form of medium chain fatty acids (MCFA) that is abundant in mother milk 
in particular, Lauric acid. It has anti-fungal, antiviral properties (Baldioli et al., 1996).Short term preservation can be easily achieved by pasteurizing the milk at $72{ }^{\circ} \mathrm{C}$ for 20 mins (Seow and Gwee, 1997). Small changes in aroma, either after processing, could be the important determinants of the degree of consumer acceptance of the product. Lin and Wilkens (1970) reported that $\delta$-octalactone, $\delta$-decalactone, and octanol are the major volatile components of coconut meat extracted by distillation. Other compounds identified were 2-heptanol, hexanol, 2-nonanone, 2-octanol, 2-nonanol, octanol, 2-undecanone, ethyl decanoate, 2 undecanol, 2-phenylethanol, benzothiazole, $\alpha$ -undecalactone, and dodecanoic acid. Predominant compounds were butanol, hexanol, heptanol, 2-heptanol, octanal, nonanal, 1-octanol,2-nonanol, $\alpha$ hexalactone,nonanol, octanoic acid, ethyl octanoate, decanal, $\delta$-octalactone, decanol, nonanoic acid,1-undecanol, and $\delta$ decalactone (Jirovetz et al., 2003). Hence, this work focused on determining the volatile compound that occur in pasteurized coconut milk, which ultimately could be related to flavor changes in the product.

\section{Materials and Methods}

\section{Collection of coconut and extraction of coconut milk}

Coconut (West Coast Tall) Variety was purchased from Coconut Research Station, Veppenkulam, Thanjavur district. Spices (Cardamom) were purchased from Thadiyankudisai, Kodaikanal. Coconut milk extracted by grinding process and squeezing out of milk through cleaned muslin cloth likewise cardamom was powdered using mixer grinder and outer layer of husks was removed. The powder of the cardamom was sieved and used as a flavouring agent in flavoured coconut milk. Commercial coconut milk was purchased from department store, used as control.

\section{Sample preparation}

The coconut milk sample was vacuum filtered through paper (What man filter paper No.1) for homogenization without heat. $10 \mathrm{ml}$ of sample was extracted with $100 \mathrm{ml}$ of HPLC grade hexane in a DURAN laboratory bottle, equipped with a magnetic stirrer, at low speed for $30 \mathrm{~min}$ at room temperature. Extractions were carried out 3 times. The hexane fractions containing the volatile compounds were pooled and further purified (nonvolatile removed) by high vacuum distillation at ambient temperature for $2 \mathrm{hr}$ and then at $50^{\circ} \mathrm{C}$ for 1 hour. Volatiles were condensed in a trap cooled with liquid nitrogen. The resulting aroma extract was evaporated to $5 \mathrm{ml}$ under a gentle steam of $\mathrm{N}_{2}$ gas and then dried over $2 \mathrm{~g}$ anhydrous $\mathrm{Na}_{2} \mathrm{SO}_{4}$ to remove water. Extracts were then concentrated to a final volume of $250 \mu \mathrm{L}$ before analysis.

\section{Gas Chromatography -Mass Spectrometry analysis}

GC-MS was conducted using a 6890 GC/5973 mass selective detector (MSD) system (Aglient Technologies, Palo Alto, Ca., U.S.A). Aroma extracts $(1 \mu \mathrm{L})$ were injected in hot splitless mode $(0.5 \mathrm{~min}$ split valvedelay time). Separate were performed on nonpolar (HP-5; 60m length, $0.25 \mathrm{~mm}$ i.d and $0.25 \mu \mathrm{m}$ film thinkness; Quadrex Corp., New haven, Conn., USA.). The GC oven temperature was programmed as follows: initial temperature of $40^{\circ} \mathrm{C}$ held for 5 mins, raised at a rate of $2^{\circ} \mathrm{C} / \mathrm{min}$ to $60^{\circ} \mathrm{C}$, raised at a rate of $20^{\circ} \mathrm{C} / \mathrm{min}$ to $90^{\circ} \mathrm{C}$, raised at a rate of $10^{\circ} \mathrm{C} / \mathrm{min}$ to $200{ }^{\circ} \mathrm{C}$, and then held at this temperature for $20 \mathrm{~min}$. The carrier gas was helium at a flow rate of $1.7 \mathrm{ml} / \mathrm{min}$. Injector and MSD transfer line were held at $250{ }^{\circ} \mathrm{C}$. 
MSD conditions were as follows: electron impact ionization voltage was 70 electron volts, scan range was 30 to $300 \mathrm{~m} / z$ at a rate of $2.74 \mathrm{scan} / \mathrm{s}$.

\section{Results and Discussion}

In the present study, the volatile compounds presented in coconut milk samples were analyzed by GC-MS analysis. The results revealed that there are ten compounds were identified in plain coconut milk. It contain the bioactive compounds such as tetracontane, it has strong antimicrobial activity, which can destroy food borne pathogens prevent from many disease and 2 hexonal was used in fruit and vegetable processing and preservation (Fig. 1 and Table 1).
Volatile compound such as Heptadecane, Pentane, 3-ethyl-2,4-dimethyl, Ethanone, 1(3-ethyloxiranyl), Tetrahydrofuran, 2,2dimethyl were identified in flavoured coconut milk. Heptadecane is a major component of Spirulina platensis, which contains high levels of proteins, amino acids, vitamins, beta carotene.It has been shown that the strong antioxidative effects of have therapeutic benefits in renal disease and inhibit the proliferation of human liver cancer cells (Fig. 2 and Table 2).

In commercial coconut milk, Pentane, 3ethyl-2,4-dimethyl, Etrahydrofuran, 3-Hexen-2-one, Heptacosanol, 2-Pentanone, 3-ethyl-3-methyl were identified (Fig. 3 and Table 3).

Fig.1 Chromatogram obtained from GC-MS with plain coconut milk

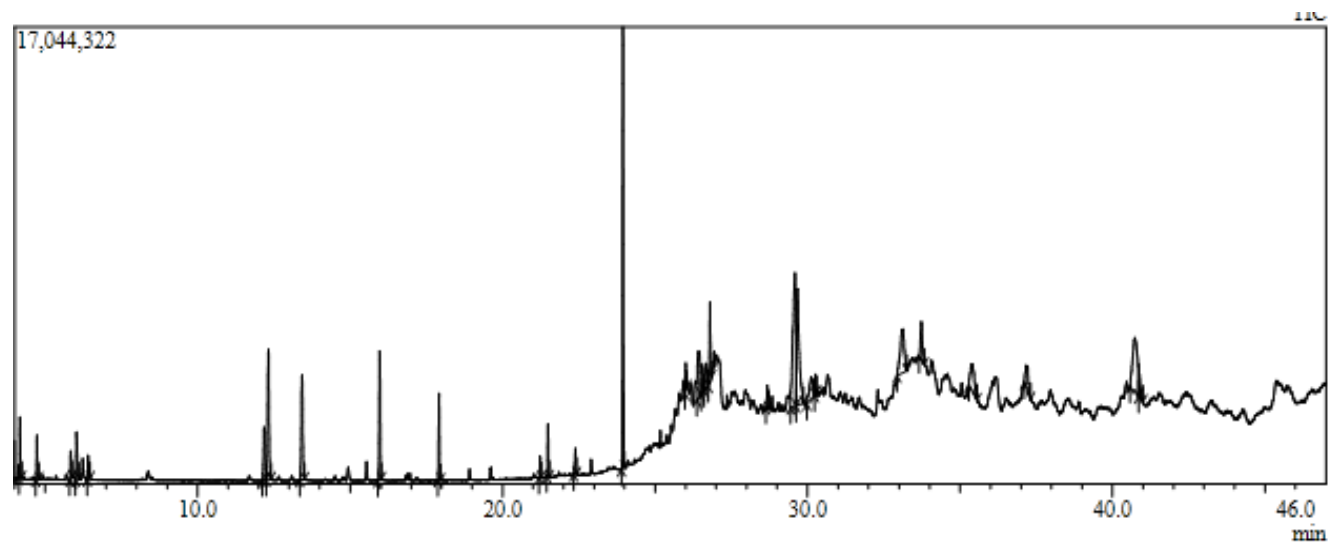

Fig.2 Chromatogram obtained from GC-MS with flavoured coconut milk

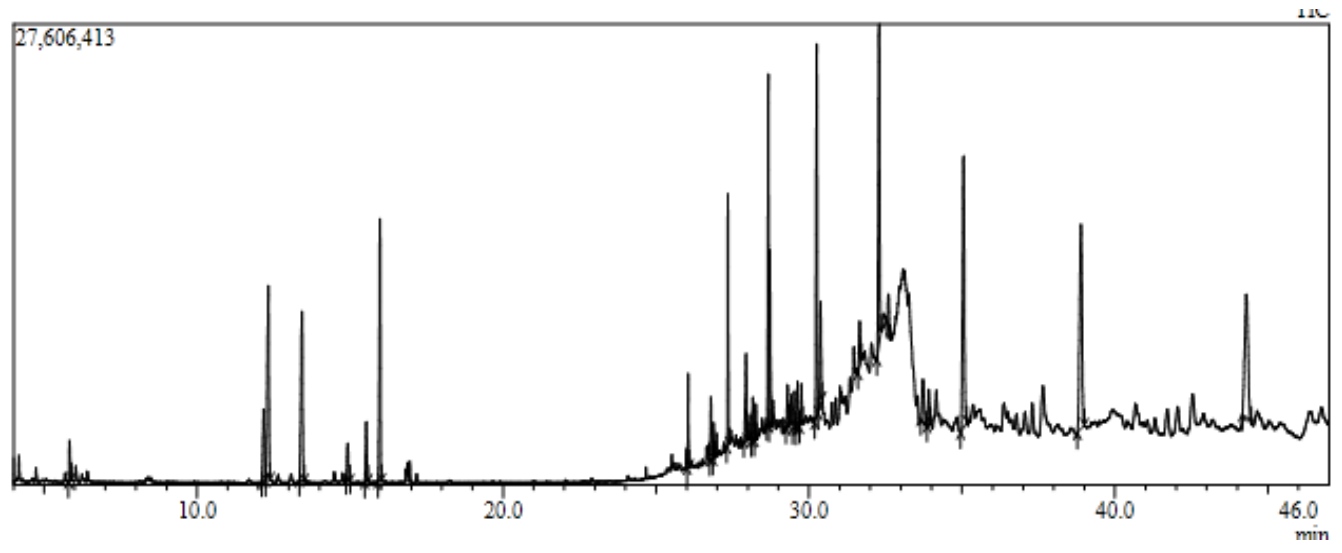


Fig.3 Chromatogram obtained from GC-MS with commercial coconut milk

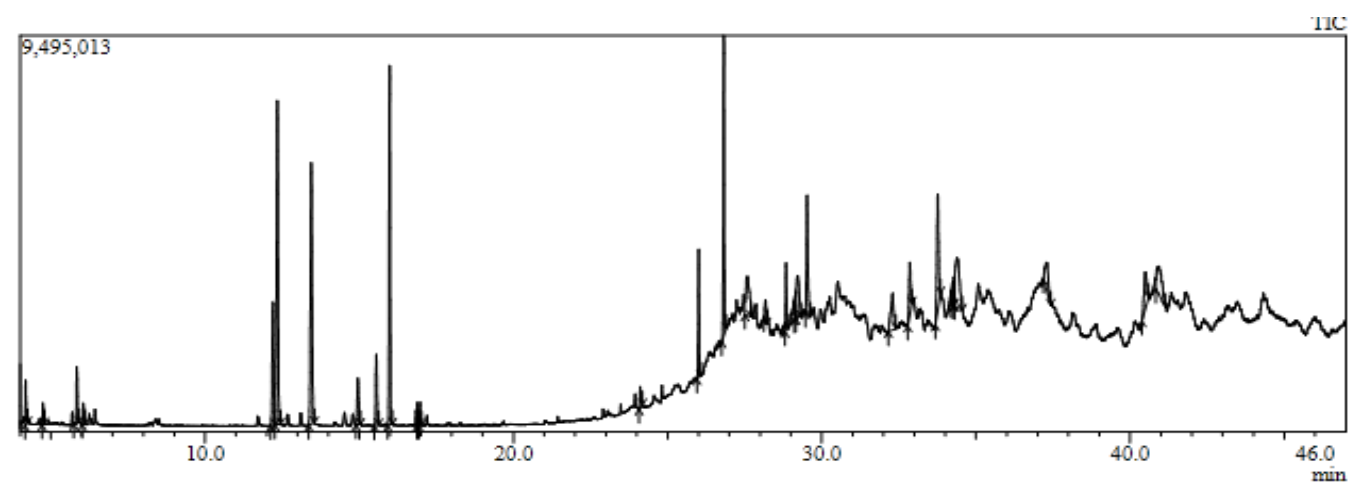

Table.1 Volatiles compound identified in plain coconut milk by GC-MS analysis

\begin{tabular}{|c|c|c|}
\hline Retention time (min) & Name of the compound & Peak area (\%) \\
\hline 4.174 & 2-Pentanol, 2-methyl- & 1.52 \\
\hline 4.731 & 3-Pentanol, 3-methyl- & 1.23 \\
\hline 5.840 & 2-Hexanone & 0.85 \\
\hline 6.031 & Cyclopentanol, 1-methyl- & 1.64 \\
\hline 6.412 & 2-Hexanol & 6.412 \\
\hline 12.185 & Tetrahydrofuran, 2,2-dimethyl- & 2.58 \\
\hline 17.915 & Eucalyptol & 2.21 \\
\hline 21.488 & alpha.-Terpineo & 1.26 \\
\hline 22.391 & Geraniol & 0.87 \\
\hline 26.005 & Heptadecan & 0.70 \\
\hline 28.680 & Tetracontane & 0.77 \\
\hline 29.660 & 1-Hexacosano & 10.18 \\
\hline 30.115 & Pentatriacontane- & 2.56 \\
\hline 33.124 & & 5.61 \\
\hline
\end{tabular}

Table.2 Volatiles compound identified in flavoured coconut milk by GC-MS analysis

\begin{tabular}{|c|c|c|}
\hline Retention time (min) & Name of the compound & Peak area (\%) \\
\hline 26.793 & Dodecanoic acid & 1.33 \\
\hline 26.885 & Heneicosane & 0.66 \\
\hline 27.351 & Heptadecane & 3.58 \\
\hline 27.942 & Pentadecane, 2,6,10-trimethyl & 2.08 \\
\hline 28.163 & Pentadecane, 8-hexyl- & 1.07 \\
\hline 28.266 & Heptadecane, 2-methyl & 0.63 \\
\hline 28.669 & Heptadecane & 6.38 \\
\hline 29.298 & Eicosane & 1.05 \\
\hline 5.831 & 2-Hexanone & 0.80 \\
\hline 12.176 & Tetrahydrofuran, 2,2-dimethyl & 2.25 \\
\hline 12.328 & Pentane, 3-ethyl-2,4-dimethyl & 6.31 \\
\hline 13.427 & Ethanone, 1-(3-ethyloxiranyl)- & 5.67 \\
\hline 14.923 & Hexane, 2-nitro- & 1.06 \\
\hline 15.529 & 2-Pentanone, 3-ethyl-3-methyl- & 1.41 \\
\hline
\end{tabular}


Table.3 Volatiles compound identified in commercial coconut milk by GC-MS analysis

\begin{tabular}{|c|c|c|}
\hline Retention time (min) & Name of the compound & Peak area (\%) \\
\hline 4.182 & 2-Pentanol, 2-methyl- & 0.99 \\
\hline 4.744 & 3-Pentanol, 3-methyl- & 0.50 \\
\hline 5.842 & 2-Hexanone & 1.50 \\
\hline 6.051 & Cyclopentanol, 1-methyl- & 5.59 \\
\hline 12.205 & etrahydrofuran, 2,2-dimethyl & 13.52 \\
\hline 12.347 & Pentane, 3-ethyl-2,4-dimethyl & 1.94 \\
\hline 14.958 & Hexane, 2-nitro- & 2.26 \\
\hline 15.554 & 2-Pentanone, 3-ethyl-3-methyl- & 10.10 \\
\hline 15.988 & 3-Hexen-2-one & 0.49 \\
\hline 16.889 & 1-Nonen-4-ol & 0.57 \\
\hline 24.111 & n-Decanoic acid & 3.51 \\
\hline 27.589 & 1-Heptacosanol & 1.74 \\
\hline 28.840 & delta.-Dodecalactone & 2.70 \\
\hline 32.296 & 2-Methylhexacosane - & \\
\hline
\end{tabular}

Plants contains variety of phytochemical components, many of them are biologically active compounds and known to have pharmacological activities ( $\mathrm{Gu}$ et al., 2014). The bioactive secondary metabolites have been shown to reduce the risk and progression of diseases such as cancer, cardiovascular disease, neurodegenerative diseases, etc by scavenging free radicals through various biological mechanism (Ansari and Khodagholi, 2013).

The results of GC-MS indicated that coconut milk samples contained numerous bioactive components belongs to various classes such as polyphenols, alkaloids, flavonoids, steroids that will provide health benefits. Coconut milk rich in antioxidants, which prevents free radical damage. It can help reverse previous damage and delay ageing process. Coconut can be effectively processed into coconut milk beverages as a substitute for cow milk beverages with improved nutritional value for health concerned consumers.

\section{Acknowledgement}

The authors would like to thank Dr. N. Senthil, Ph.D, Project Director, Center of innovation and Professor and Head, Department of Biotechnology and Mr. S. Vellai Kumar, Assistant Professor, Department of Biotechnology, Agricultural College and Research Institute, Tamil Nadu Agricultural University, Madurai for providing infrastructure and necessary research facilities to conduct GC-MS analysis.

\section{References}

Anjaya, C.C., Arlina, M.M. and Andawiyah, D.R.1996. Effect of extraction, antioxidant, bleaching agent on the shelf life of coconut milk packed in retort pouch. Bul.Teknol.Indust.Pangan. 7(2): 54-62.

Ansari, M. and Khodagholi, F. 2013. Natural products as promising drug candidates for the treatment of Alaheimer disease: molecular mechanism aspect. Curr Neuropharmacol; 11(4):414-429.

Baldioli, M., Servili, M., Perretti,G. and Montedoro, GF. 1996. Journal of the American oil Chemists Society. 73: 1589-1593.

Brown, T. 2014. The Health Benefits of Coconut Milk. Demand Media. 
http://healthyeating.sfgate.com/healthbenefits-coconut-milk2031.html,11-102014

Gu, R., Wang, Y., Long, B., Kennelly, E., $\mathrm{Wu}, \mathrm{S}$. and Liu, B.2014. Prospecting for bioactive constitutes from traditional medicinal plants through ethno botanical approrahes. Biol Phram Bull: 37(6):903-915.

Jirovetz, L., Buchbauer, G. and Ngassoum, M.B. 2003. Solid-phase micro extraction headspace aroma compounds of coconut (Cocos nucifera L.) milk and meat from Cameroon. Er nahrung 27:300-3

Lin, F.M. and Wilkens, W. F. 1970. Volatile flavor components of coconut meat. $\mathrm{J}$ Food Sci 35:538-9

Rehman, S., Ahmad, M.M., Almas, Y.,
Amna, A., Kausar and Muntaha, S.T. 2004. Sensory and nutritional evaluation of coconut natural milk blend. Pak. J. Life soc. Sci, 2(2):104108.

Seow, C.C. and Gwee,C.N. 1997.Coconut milk: Chemistry and technology. International Journal of Food Science and Technology, 32, 189-201.

Simuang, J., Chiewchan, N. and Tansakul.2004.Effects of fat content and temperature on the apparent viscosity of coconut milk. J. Food Eng., 64(2): 193-197.

Tangsuphoom, N. and Coupland, J.N. 2005. Effect of heating and homogenization on stability of coconut milk emulsion. J. Food Sci. 70(8): 466-470.

\section{How to cite this article:}

Kokilavani, S., G. Sashidevi, P. Venilla and Arun Kumar, R. 2017. Identification of Volatile Compound in Coconut Milk Samples Using GC-MS. Int.J.Curr.Microbiol.App.Sci. 6(11): 1140-1145. doi: https://doi.org/10.20546/ijcmas.2017.611.136 